\title{
Edyta Januszewska, Heterotopie dziecięcego uchodźstwa. Syryjczycy w Libanie [Child Refugee Heterotopies: Syrians in Lebanon], Wydawnictwo Impuls, Kraków 2019, pp. 304
}

\begin{abstract}
Research into other's suffering can only be justified if alleviating that suffering is an explicit objective.
\end{abstract}

(Turton, 1996, p. 96)

Research focused on people from socially vulnerable groups, especially refugees, is extremely challenging. The reasons for this are problems with access to the study groups and reaching the respondents, and sometimes also their reluctance to share their stories and lack of trust in researchers. Yet, Edyta Januszewska made an effort to carry out a qualitative research project in a particularly inaccessible place and group: among Syrian refugees living in Lebanon. The results of that research, together with detailed description of the theoretical context and source literature background, are included in the publication Heterotopie dziecięcego uchodźstwa. Syryjczycy w Libanie [Child Refugee Heterotopies: Syrians in Lebanon].

In this review I will only refer to one area of the monograph: the description of the research carried out by the Author. I begin with characterizing the research and then I analyze its ethical aspects, especially the ones related to researching vulnerable groups. The frame of reference is the principles of ethical social research identified by Earl Babbie (2004): voluntary participation, no harm to the participants, and informed consent.

1 Doctoral School of Social Sciences, University of Białystok, Poland. E-MAIL: k.potoniec@uwb.edu.pl ORCID: https://orcid.org/0000-0002-0536-9398 


\section{CHARACTERISTICS OF E. JANUSZEWSKA'S RESEARCH}

The research described in the book was carried out among Syrian refugees living in Lebanon in 2017. Edyta Januszewska did it during her one-month stay in the country, when she was volunteering as an English teacher at schools run by a Christian missionary organization in refugee camps in the Beqaa Valley (near the city of Zahle). In the research she was assisted by a guide and interpreter (a Syrian refugee working as a teacher at a school run by the missionary organization) she had trained before.

The author formulated the following research problem: "How is the camp perceived by the refugees and how is it 'domesticated', 'familiarized' and constructed by them?” (p. 94). She analyzes four areas: the respondents' flee from Syria, their time and space in Lebanon, and the "domestication" of their space in refugee camps (p. 17).

In her research, Januszewska alludes to the phenomenological and constructivist approach. She applies the biographical method (with the partially structured interview technique) and participatory observation (using an observation journal).

The study group mostly included Syrian refugees (48 persons) as well as one male Syrian volunteer and one female Lebanese NGO worker. The respondents' age was between 10 and 55 . The information included in the monograph is insufficient to determine how many children (and of what age) took part in the research, because the first age group includes people aged 10-25, without any further specification.

The Author describes the selection of the study sample this way: "The main way I came into contact with the people was visiting them with Rasza [Januszewska's guide and interpreter - K.P.] in refugee camps or tents and asking them whether they would agree to give me an interview” (p. 108). One person was the interpreter's acquaintance. Some respondents were people met accidentally or acquaintances of the ones who had already taken part in the research (pp. 108109). The research among refugees was done at their places of residence: camps, hen houses, stables, tents, rented apartments, or uninhabited buildings (p. 104).

\section{ETHICAL ASPECTS IN JANUSZEWSKA'S RESEARCH}

In this section of the paper, I will focus on the ethical aspects of doing social research identified by Earl Babbie, referring to the reviewed monograph: the principles of voluntary participation, no harm to the participants, and informed consent. 


\section{VOLUNTARY PARTICIPATION}

Doing research is obviously some interference in the lives and privacy of the respondents. Participation in research may mean sharing private and personal information. Thus, the researchers should do their best to prevent the participants from feeling forced to participate in the study. This principle seems unquestionable and obvious. However, it becomes questionable whenever there is a dependence or power relationship between the researcher and the participants. Earl Babbie (2004) asks, for example: Can students asked to participate in a study by their teacher actually refuse? Won't they fear the consequences of their refusal, e.g., a lower final grade in the subject taught by that teacher? (p. 516).

Similar dilemmas arise in relation to research done among refugees, being one of particularly vulnerable groups. Their rights and liberties are often very limited. Their circumstances, and sometimes even lives, depend on others (aid organizations, governmental institutions, international organizations or agencies). A refugee without a refugee status or a residence permit can suffer a lot of abuse, which we often hear of on the media. In this situation, a stranger, especially a person related to aid organizations, appears to have a greater influence on various matters and be potentially helpful. Thus, individuals may agree to participate in a study because they hope it will help improve their lives (Jaworska, Alieva, \& Boryczko, 2019).

Given all these issues, it is extremely important to select the study sample properly and to plan the whole process so as to minimize the issues resulting from the disproportion between the researcher and the respondent and make sure that participation in the research is really voluntary.

The content of the reviewed monograph does not provide explicit information on how Edyta Januszewska ensured her respondents' voluntary participation in the research. Data is particularly scarce regarding how the researcher minimized her own and her interpreter's influence on the respondents' decision about taking part in the research and what the process involved in the case of students taught by the Author.

The interpreter, who also served as the Author's guide, worked as a teacher and a worker of an international organization and was a Syrian refugee herself. As we can conclude from many utterances of the interviewed Syrians reported in the book, they saw those organizations as a hope for support, as they could have a direct impact on the refugees' future lives (pp. 96, 198-202). She was a teacher too, and the respondents often pointed out that education of their children was very important for them and that it was very hard to ensure that education in Lebanon (pp. 257-259, 266-267, 275). We do not know how the Researcher minimized 
the potential influence of her guide resulting from the disproportion in access to resources (working at an aid organization and at a school) and ensured the sense of voluntary participation in the research.

The same refers to the Author herself. For the refugees, she was a "stranger", with better capabilities and potential influence. Januszewska writes: "Since I was not from Germany, they didn't look to me hoping I would help them. I didn't bring them euros or dollars, so they didn't expect such aid from me” (p. 147). The researcher does not explain why she concludes so. Actually, another entry in Januszewska's observation journal seems to contradict that thesis. "I was unprepared to the looks of ill and disabled children and their parents, crying: Edyta, please help us! That was the hardest ordeal for me. The Syrians begged me to find specialist doctors in Poland who could come there and treat their children. They showed me medical documentation, hoping I would help them” (p. 107). The monograph does not include any information on what the Researcher did to explain the respondents what her role was and what they could expect of her.

The principle of voluntary participation is a great challenge in the context of research involving children. This aspect is also present in the reviewed monograph. Januszewska used five children (students from the school she worked at) in her research. Why these particular students were chosen is not explained in the book. The children took photos of their surroundings, daily activities, and whatever was important for them. The photos were taken with disposable cameras. Then, the Researcher interviewed the children. This description of the research procedure raises a number of questions: Did the children have any choice as to participating in the research? Could they refuse? Was their right to choose real or just theoretical, because they counted on a kind of reward, even if it was only the teacher's interest in them?

\section{NO HARM TO THE PARTICIPANTS}

No research participant may suffer any harm as a result of doing the research (Babbie, 2004, p. 516). This principle means that the researcher may not reveal any information concerning their respondents that could harm them in any way. Besides, in accordance with this principle, the researcher is obliged to do whatever they can to protect the respondents from any discomfort or harm resulting from participating in the research process. They need to plan particular elements of the research carefully and to predict any potential problems that could result from the respondents recalling difficult events in their lives or confronting unpleasant situations (Babbie, 2004; Flick, 2011). 
In the context of the reviewed book, it is worth pointing to the following aspects connected with the "no harm" principle: applying this principle in research done among refugees, implementing the concept of dual imperative, and the use of the reciprocal benefit principle.

In the case of research involving socially vulnerable people such as refugees, the "no harm" principle is especially valid, because the vast majority of refugees (up to 84\%; Jaworska, Alieva, \& Boryczko, 2019) suffer from the Post-Traumatic Stress Disorder (PTSD). According to Uwe Flick (2011), it does not mean that these groups cannot be studied, but - like in any other case - we need to think whether 'using' them is worthwhile (p. 124).

The refugees studied by Edyta Januszewska discuss very difficult, often traumatic topics: their previous lifestyles lost due to the war, the flight from Syria, leaving their families behind, health and mental problems afflicting themselves and their family members, war experiences, and the dramatic situation experienced in Lebanon. Entries in the Author's field journal show how difficult it was for the respondents to talk about this. She noted down again and again that they were crying when giving the interviews, and some of them were even unable to continue: "the man was crying hard” (p. 109); "A sixty-year-old man was being interviewed. After about four minutes, he began to cry, and a moment later, he ran out of the room, sobbing. His fifty-year-old wife was also crying a lot. I had never met a man who was crying so hard before. He was crying during the entire interview” (pp. 152-153); "She cried a lot while we were talking” (p. 158); "I was interviewing a forty-two-year-old Syrian man [...] who was crying loudly” (p. 228).

Studies carried out among participants of research projects concerning traumas, who experienced strong and difficult emotions when participating in them, show that as they recall it sometime later, most respondents do not regret or assess negatively the general experience of participation in the research (Legerski \& Bunnell, 2010; Jaworska, Alieva, \& Boryczko, 2019). The Author also points this out. She states that for her respondents, giving the interviews was a kind of katharsis (p. 108), and in some cases it had a therapeutic effect (p. 273).

According to some researchers, in the case of such vulnerable groups as refugees, just doing no harm to the participants is not enough. They believe that this principle should be accompanied by a positive change in the participants' lives (Pittaway, Bartolomei, \& Hugman, 2010) and if possible, alleviating their suffering (Turton, 1996). Researchers also stress the need to implement the dual imperative principle: on the one hand, to meet academic research standards, and on the other hand, to make sure that the obtained research results contribute to the improvement of the system of protection of refugees and the development of policies to support 
them (Jacobsen \& Landau, 2003). Therefore, the aim of many studies done among refugees is to influence decision-makers, aid organizations and agencies, formulating recommendations for their activities so that they would support refugees to a greater extent and help improve their situation (Jacobsen \& Landau, 2003).

With regard to justifying her research, Edyta Januszewska points out that refugees' situation is a significant social problem, practically absent from the scientific discourse in Poland. In her work she also looks for confirmation of the two theses she formulates. One is that "refugee camps are heterotopic places", and the other one assumes that "refugee camps are places that can be constructed and domesticated" (p. 14). The aim of the monograph is to show that "in the situation of having to leave their country, abandon their time and space rooted in the previous life, together with cultural and social norms, refugees construct their new topos (place)” (p. 15).

In the monograph the Author does not formulate any recommendations concerning the improvement of refugees' situation. At the end of the publication she only asks: "what direction is the contemporary globalized world going in if a human must find their place and define a new space for themselves as a nomad and refugee ('waste')? Is it going towards a place and space connected with finding residence, settling and taking root, or towards oscillation on the verge of losing their identity? Will they find their home in the secure haven of their place or will they be forced to continue wandering, and finally lose their dignity and selfrespect?” (pp. 275-276).

The "no harm" principle can also have a much more advanced form - the principle of reciprocal benefit. It has evolved as an antidote to problems reported by the studied refugees. They point out that researchers actually exploit them, not informing them of the research objective or results, not respecting their subjectivity or autonomy. "We never heard from them [the researchers] again - we decided then that we would never work with researchers again. They stole our stories" (Pittaway, Bartolomei \& Hugman, 2010, p. 236).

From the refugees' point of view, “their stories” are only beneficial for the researchers. Therefore, Pittaway, Bartolomei, and Hugman (2010) suggest that research done in refugee communities be based on the principle of reciprocal benefit. In their model, the researcher agrees the framework of the research and all the principles of doing it with the community, including the assurance that the collected material belongs to the community and can only be used at their consent. The benefit for the community is the workshops concerning human rights conducted by a team of researchers, which become the starting point for the research (Pittaway, Bartolomei, \& Hugman, 2010). 
In the reviewed monograph there is no information on how the Author solved this difficult situation. We only know that she never met the respondents again.

\section{INFORMED CONSENT}

Due to the sensitivity of subjects discussed in this kind of research, the personal character of information provided by the respondents and exposing them to discomfort or going through difficult emotions again, the principle of informed consent to participation in the research is especially important. Informed consent means that the participants agree to take part in the research with full awareness of possible dangers (Babbie, 2004, p. 517). They are informed of the character, objective and potential consequences of the research and their right to withdraw from it at any time. It is assumed that the consent should be written. It may have the form of a declaration or a bilateral agreement between the participant and the researcher (Babbie, 2004; Flick, 2011).

As regards research into refugees, due to the specific situation and special vulnerability of that group, we apply the principle of iterative consent. It is based on the assumption that "consciously giving consent to something is a dynamic process, not a one-time act after which the participant loses control of the information obtained by the researcher" (Jaworska, Alieva \& Boryczko, 2019, p. 214). Practically, it means that the researcher does not stop with obtaining the participants' consent once but verifies that decision in the course of the research process, allowing the respondents to withdraw the consent given previously.

In research practice, it may be a serious challenge to ensure the refugees express their informed consent to participating in the research. This problem is especially visible in research carried out in refugee camps and in research involving children.

Linda Bartolomei writes: "When I go into a horrendous camp situation as a white researcher, the people are so desperate for any form of assistance they would agree to anything just on the off-chance that I might be able to assist. It makes asking for permission to interview them or take photographs a farce... What does 'informed consent' mean in an isolated refugee camp with security problems and no proper interpreters?” (Pittaway, Bartolomei \& Hugman, 2010, p. 234). Therefore, she recommends the use of the principle of reciprocal benefit in research involving refugees, as it builds the subjectivity and autonomy of the studied communities and ensures measurable profits for the refugees (e.g., workshops devoted to them).

Doing research with children confronts researchers with the question of who should express the consent to minors' participation in the research: should it be 
the children's parents only, giving consent on their behalf, or should the children also be asked if they want to take part in the research? (Main, 2008). As argued by Uwe Flick (2011), in situations when obtaining an informed consent from the participants is difficult or impossible (e.g., as regards children), we should explicitly describe the adopted principles, which may lead to informed consent or be regarded as its acceptable substitute. In the former case, researchers should make a written declaration stating that they have informed the participant of the character of the research and that the participant has agreed to take part in the research afterwards. In other cases, they need to think who could give consent on the participant's behalf and whether this is justifiable (p. 128).

Describing the concept and procedure of doing her research, Edyta Januszewska does not specify how her respondents were informed about the research, its aim, potential (including negative) consequences of participation or the possibility to withdraw from the research at any time. We learn that when the refugees were asked to participate in the research, "they most often agreed" (p. 108). But the researcher does not explain how the consent was expressed, what its form was or what potential substitutes she used, either in the case of adults or children.

As we read fragments of the Author's field journal describing her first contact with the interviewed children, we do not find any information on how the principle of informed consent was respected: "Then, we went a bit further, and we saw two tents by the road. The fifteen-year-old girl who lived there also gave us an interview” (p. 109).

\section{CONCLUSION}

If research involving refugees is carried out in accordance with ethical and methodological principles, it can be an important instrument of exerting influence on decision-makers and change the lives of refugees (Jacobsen \& Landau, 2003). Regardless of what research methods are used and how ethical aspect of the research is ensured, the description of methodology of the conducted research should definitely provide the point of reference to evaluate its scope and course and make it possible for other researchers to repeat or continue it later. Detailed explanation of the research procedure enhances the value of the research itself, and this leads to the improvement of refugees' situation (Jacobsen \& Landau, 2003), making the effort connected with the research process justified and valuable, both for the researcher and for the participants. 


\section{References}

Babbie, E. (2004). Badania społeczne w praktyce. Warszawa: Wydawnictwo Naukowe PWN.

Flick, U. (2011). Projektowanie badania jakościowego. Warszawa: Wydawnictwo Naukowe PWN.

Jacobsen, K., \& Landau, L. (2003). Researching Refugees: Some Methodological and Ethical Considerations in Social Science and Forced Migration. Geneva: UNHCR.

Jaworska, D., Alieva, K., \& Boryczko, M. (2019). Badania wśród uchodźców i przymusowych migrantów - rozważania metodologiczne i etyczne. Przegląd Socjologii Jakościowej, 15(2), pp. 202-227. DOI: 10.18778/1733-8069.15.2.11.

Legerski, J.P., \& Bunnell, S.L. (2010). The Risks, Benefits, and Ethics of Trauma-Focused Research Participation. Ethics \& Behavior, 20(6), pp. 429-442. DOI: 10.1080/10508422 .2010 .521443 .

Main, I. (2008). Uchodźcy w nauce polskiej - stan badań i literatury, metodologia i etyka badań. In: I. Czerniejewska, \& I. Main (Eds.), Uchodźcy: teoria i praktyka (pp. 21-33). Poznań: Stowarzyszenie „Jeden Świat”.

Pittaway, E., Bartolomei, L., \& Hugman, R. (2010). 'Stop Stealing Our Stories': The Ethics of Research with Vulnerable Groups. Journal of Human Rights Practice, 2(2), pp. 229-251. DOI: 10.1093/jhuman/huq004.

Turton, D. (1996). Migrants and Refugees: A Mursi Case Study. In: T. Allen (Ed.), In Search of Cool Ground: War, Flight and Homecoming in Northeast Africa (pp. 96-123). GenevaLondon-Trenton, NJ: James Currey, Africa World Press. 